\title{
Evaluasi Karakter Pertumbuhan dan Inflorescence Plasma Nutfah Kapas Introduksi dan Lokal pada Iklim Tropis
}

\section{Inflorescence and Growth Evaluation of Several Cotton Germplasm on Tropical Condition}

\author{
Jakty Kusuma $^{1 *}$ dan Muhammad Tahir ${ }^{1}$ \\ ${ }^{1}$ Dosen Jurusan Produksi Tanaman Perkebunan, Politeknik Negeri Lampung \\ Jl. Soekarno Hatta No. 10. Bandar Lampung, 35145 \\ *email : kusuma@polinela.ac.id
}

\begin{abstract}
In order to support the needs of the national textile industry, the necessary raw materials of high quality cotton, high grain yield and widely adaptable. To achieve these objectives, it is necessary the introduction of new cotton crop accession so that the resources can be available breeding elders. Given the genetic diversity and varieties of national cotton production stagnant. The study was conducted with the aim of getting the results of evaluation of growth of cotton plants introduced in tropical environments. Based on the analysis of variance, character growth, plant height, number of branches and monopodial simpodial, and time of harvest showed significant differences in the level of $1 \%$. While the character of days to flowering and boll opening age showed significant differences in the level of 5\%. There was variation in plant height were heterogeneous due to genetic differences. Differences in flowering dates, age boll opening and harvesting with significant variation is caused by environmental influences. Anticipated environmental factors that have the most primary role is long irradiation, recorded some sensitivity to fotoperiodisitas accession. The results of the study recommend accession CRIS-664 and CRIS-342 as source code elders with early maturity, because it has a lifespan of flowering and harvesting age equal even faster than local cultivars.
\end{abstract}

Key words: cotton, germplasm, introduction, inflorescence

Diterima: 20 Agustus 2016, disetujui 20 September 2016

\section{PENDAHULUAN}

Tanaman kapas termasuk kedalam Sasaran Komoditas Perkebunan 2015 - 2019 Kementerian Pertanian yang diharapkan memiliki laju pertumbuhan produksi sebanyak 17,49\%. Kapas merupakan bahan baku utama dalam pemenuhan kebutuhan industri tekstil nasional yang permintaan nya selalu meningkat dari tahun ke tahun, dengan nilai ekspor sebesar \$12.600.000,00 pada tahun 2014 (Kemenperin, 2015). Ironisnya, nilai ekspor tekstil nasional tersebut berbanding terbalik dengan ketersediaan bahan baku dari industri teksil, yakni fiber kapas. Produksi kapas di Indonesia pada tahun 2014 terhitung sebanyak 1,871 ton dan memiliki produktivitas sebanyak $288 \mathrm{~kg} / \mathrm{ha}$ (Kementerian Pertanian, 2014). Dengan produktivitas yang sangat rendah, hasil tersebut hanya bisa memenuhi sebanyak 0,5\% kebutuhan serat nasional (Balittas, 2014), dan selebihnya 
sebanyak > 99\% diimpor dari berbagai negara produsen kapas. Situasi ini diperparah dengan penurunan lahan pertanaman kapas yang semula 10.194 ha pada tahun 2010 menjadi 8.738 ha pada tahun 2013 .

Hingga saat ini, terdapat ada 20 varietas kapas yang dirilis oleh pemerintah melalui Balittas (Balai Penelitian Tanaman Pemanis dan Serat). Jumlah varietas yang sudah dirilis dirasa kurang mampu memenuhi kebutuhan bahan baku industri tekstil nasional. Perakitan varietas baru merupakan hal penting yang harus segera dilakukan. Sebagai upaya dalam meningkatkan produksi kapas nasional, meningkatkan keragaman populasi melalui proses introduksi adalah hal yang mutlak untuk dilakukan. Kultivar introduksi memiliki manfaat sebagai sumber plasma nutfah baru untuk proses seleksi tetua.

Penggunaan kultivar introduksi dengan spesies yang sama atau berbeda dengan kapas kultivar lokal merupakan salah satu teknik dalam memanfaatkan dan mendeterminasi sifat-sifat unggul yang tidak dimiliki oleh kapas kultivar lokal. Berdasarkan laporan dari Center Institute for Cotton Research yang dikutip oleh Departmen of Biotechnology (2011), aksesi dari spesies Gossypium hirsutum merupakan breeding source bagi karakter kegenjahan, berat boll tinggi, dan hasil yang tinggi. Pada spesies Gossypium arboreum terdapat karakter penting bagi kualitas fiber itu sendiri, yaitu panjang fiber dan kandungan minyak biji yang tinggi. Spesies Gossypium arboreum memiliki karakter hasil yang tinggi dan ketahanan terhadap beberapa hama utama tanaman kapas.

Dengan mengetahui karakter-karakter penting pada plasma nutfah yang ada, maka perakitan dan pengembangan varietas kapas akan menjadi lebih mudah. Pengelolaan plasma nutfah yang baik akan memudahkan tujuan dan arah seleksi itu sendiri. Sebagai tahap awal, karakter pertumbuhan dan pembungaan merupakan karakter penting yang perlu dievaluasi, terutama pada lingkungan tumbuh yang berbeda dari asal plasma nutfah tersebut. Tujuan dari penelitian ini adalah mengevaluasi pertumbuhan dan pembungaan kapaskapas introduksi pada lingkungan tropis. Lebih lanjut, hasil pengujian adaptabilitas pertumbuhan dan pembungaan pada penelitian ini dapat dijadikan rekomendasi sumber tetua perakitan varietas kapas yang baru.

\section{METODE}

Percobaan dilaksanakan pada bulan Mei 2016 hingga Agustus 2016 bertempat di Kebun Percobaan Politeknik Negeri Lampung, dengan menggunakan metode eksperimen dengan Rancangan Acak Kelompok dengan aksesi plasma nutfah yang digunakan dalam penelitian ini sebanyak 12 aksesi yang terdiri dari spesies Gossypium hirsutum, Gossypium arboreum, dan Gossypium barbadense (Tabel 1) dan dua varietas pembanding dimana Kanesia 15 dan Kanesia 20 bertindak sebagai kontrol dengan dua ulangan.

Setiap aksesi ditanam pada polybag dengan masing masing tiga (3) benih pada setiap polybag, yang selanjutnya dilakukan penjarangan tanaman hingga satu tanaman per polybag ketika tanaman berumur 25 hari. Adapun tanaman yang tidak tumbuh dilakukan penyulaman. Sebagai informasi tambahan, aksesi tersebut didapatkan melalui material transfer agreement dengan Cotton Research Institute, Sakrand, Pakistan dan United States Department of Agriculture-Agricultural Research Service, Amerika Serikat.

Setiap satuan percobaan terdapat 10 tanaman dengan tiga tanaman sampel, jarak tanam $40 \mathrm{x} 80 \mathrm{~cm}$. Model Linier yang digunakan dalam Rancang Acak Kelompok menurut Petersen (1994) adalah sebagai berikut :

$$
\mathrm{Y}_{\mathrm{ij}}=\mu+\mathrm{g}_{\mathrm{i}}+\mathrm{r}_{\mathrm{j}}+\varepsilon_{\mathrm{ij}}
$$

Keterangan :

$\mathrm{Y}_{\mathrm{ij}} \quad=$ hasil pengamatan pada genotip ke-i dalam ulangan ke-j

$\mu \quad=$ nilai tengah pengamatan karakter yang diamati

$\mathrm{g}_{\mathrm{i}} \quad=$ pengaruh aditif dari perlakuan genotip ke- $\mathrm{i}$ 
$\mathrm{r}_{\mathrm{j}} \quad=$ pengaruh aditif dari ulangan ke- $\mathrm{j}$

$\varepsilon_{\mathrm{ij}} \quad=$ pengaruh galat percobaan dari genotip ke-i pada ulangan ke-j

i $\quad=$ genotip $(1,2,3$, .

$\mathrm{j} \quad=$ ulangan $(1,2)$

Data yang diperoleh dianalisis dengan menggunakan uji-F dan apabila hasil yang diperoleh berpengaruh nyata maka dilakukan uji nilai tengah dengan menggunakan uji BNT pada taraf 5\%. Karakter yang diamati pada penelitian ini adalah jumlah cabang monopodial, jumlah cabang simpodial, tinggi tanaman, umur berbunga, umur boll membuka, umur panen, dan sensitivitas terhadap fotoperiodisitas.

Tabel 1. Aksesi Plasma Nutfah Tanaman Kapas

\begin{tabular}{llll}
\hline No & Nama Aksesi & Spesies & Asal \\
\hline 1 & CRIS-664 & Gossypium hirsutum & CRIS, Pakistan \\
2 & CRIS-665 & Gossypium hirsutum & CRIS, Pakistan \\
3 & CRIS-666 & Gossypium hirsutum & CRIS, Pakistan \\
4 & CRIS-667 & Gossypium hirsutum & CRIS, Pakistan \\
5 & CRIS-668 & Gossypium hirsutum & CRIS, Pakistan \\
6 & CRIS-669 & Gossypium hirsutum & CRIS, Pakistan \\
7 & CRIS-670 & Gossypium hirsutum & CRIS, Pakistan \\
8 & CRIS-342 & Gossypium hirsutum & CRIS, Pakistan \\
9 & Marvi-425 & Gossypium arboreum & CRIS, Pakistan \\
10 & FDH-834 & Gossypium arboreum & CRIS, Pakistan \\
11 & SA-2467 & Gossypium barbadense & USDA-ARS, USA \\
12 & SA-2465 & Gossypium barbadense & USDA-ARS, USA \\
13 & Kanesia 15 & Gossypium hirsutum & Balittas, Indonesia \\
14 & Kanesia 20 & Gossypium hirsutum & Balittas, Indonesia \\
\hline
\end{tabular}

Khusus karakter sensitivitas terhadap fotoperiod, pengamatan mengacu kepada deskriptor yang disusun oleh IBPGR (1985) dan USDA-ARS (2015). Jika tanaman sensitif maka nilainya adalah 1, dan jika tidak sensitif maka nilainya 0 . Pengamatan penunjang dalam penelitian ini adalah curah hujan, temperatur, dan intensitas cahaya. Data curah hujan didapatkan dari Stasiun Agroklimat Politeknik Negeri Lampung, sedangkan temperatur dan intensitas cahaya diamati dengan menggunakan termometer dan luxmeter. Untuk menghitung suhu rata-rata harian digunakan rumus:

$$
\mathrm{T}=\frac{2 \mathrm{x}(\mathrm{T} \text { pagi }+\mathrm{T} \text { siang }+\mathrm{T} \text { sore })}{4}
$$

\section{HASIL DAN PEMBAHASAN}

\section{Keadaan Lingkungan Tanam}

Berdasarkan hasil pengamatan cuaca, kondisi curah hujan cukup tinggi pada saat awal penanaman (Mei) meski penanaman dilakukan pada awal musim kemarau, yang disebabkan oleh kondisi La Nina. Kondisi seperti ini terbilang bagus karena selama awal pertumbuhannya tanaman kapas memang membutuhkan ketersediaan air yang cukup. Pada saat tanaman kapas berumur 5 MST kebutuhan airnya pun berkurang. Namun selama kelembaban tanah terjaga, maka pertumbuhan tanaman kapas tidak akan terganggu. Efisiensi penggunaan air pada tanaman kapas bisa menentukan total hasil produksi per unit suplai air terhadap tanaman (Gibb dan Constable, 1995).

Selama periode tanam, jumlah hari hujan paling banyak yaitu pada bulan Mei yaitu sebanyak 17 hari, sedangkan paling sedikit pada bulan Juli, yaitu sebanyak 8 hari. Curah hujan tertinggi terdapat pada bulan 
Agustus, sekitar 109,2 mm/bulan, disaat tanaman berumur 11-12 MST. Curah hujan terendah yaitu pada bulan Juli, ketika sebagian besar tanaman memasuki masa generatif, yaitu 48,5 mm/bulan. Tipe curah hujan untuk Kebun Percobaan Politeknik Negeri Lampung dapat diketahui berdasarkan data curah hujan selama 10 tahun terakhir tahun 2006 - 2016, yaitu termasuk tipe C dengan sifat agak basah menurut klasifikasi Schimdth - Ferguson.

Selama pengamatan, pengukuran intensitas cahaya dilakukan tiga kali dalam sehari selama pertanaman. Intensitas cahaya selama pertanaman berkisar antara 938 - 1944 lux. Selama percobaan, suhu yang dicapai yaitu berkisar antara $27,1-32,6^{0} \mathrm{C}$ suhu tertinggi terjadi pada bulan Juli, sedangkan suhu terendah yaitu pada terjadi bulan Mei. Suhu optimum bagi pertumbuhan kapas adalah $30^{\circ} \mathrm{C}$ hingga $35^{\circ} \mathrm{C}$ (Reddy et al., 1992).

\section{Evaluasi Karakter Pertumbuhan dan Inflorescence}

Hasil pengamatan menunjukkan bahwa ketiga variabel pengamatan memiliki perbedaan nyata pada taraf $1 \%$ (Tabel 2).

Tabel 2.Nilai Minimum, Maximum, Rata-rata, Koefisien Variasi dan F-hitung 3 Karakter pada 14 Aksesi Tanaman Kapas

\begin{tabular}{lllcllll}
\hline No & \multicolumn{1}{c}{ Karakter } & \multicolumn{1}{c}{ Min } & \multicolumn{1}{c}{ Max } & \multicolumn{1}{c}{$\bar{X}$} & \multicolumn{1}{c}{ KV (\%) } & F-H & \\
\hline 1 & Tinggi Tanaman & 84.92 & 171.16 & 128.07 & 8.11 & 16.87 & $* *$ \\
2 & Jumlah Cabang Monopodial & 1.01 & 2.13 & 1.75 & 4.90 & 2.21 & $* *$ \\
3 & Jumlah Cabang Simpodial & 13.54 & 22.31 & 17.96 & 9.96 & 10.07 & $* *$ \\
4 & Umur Berbunga & 54.29 & 140.22 & 72.94 & 12.21 & 21.01 & $*$ \\
5 & Umur Boll Membuka & 93.11 & 121.82 & 88.03 & 8.07 & 19.12 & $*$ \\
6 & Umur Panen & 120.21 & 159.77 & 113.55 & 15.75 & 22.20 & $* *$ \\
\hline
\end{tabular}

Keterangan: * = Berbeda nyata pada taraf $5 \%$; ** = Berbeda nyata pada taraf $1 \%$ menurut uji $\mathrm{F}$; ns $=$ non signifikan

Karakter tinggi tanaman berkisar antara 84,92 cm hingga 171, $16 \mathrm{~cm}$, dengan rata-rata $128,07 \mathrm{~cm}$. Variasi tinggi antar spesies kapas diduga akibat perbedaan konstitusi genetik masing-masing individu. Perbedaan didalam spesies yang sama lebih diakibatkan oleh faktor lingkungan, dimana perbedaan unsur hara dapat menyebabkan laju pertumbuhan yang berbeda pula. Hasil serupa diungkapkan oleh Hussain et al. (2007), Wankhade et al. (2002), Saeed et al. (1996) dan Bolonhezi et al. (1999). Jumlah cabang monopodial berkisar antara 1,01 hingga 2,12 dengan rata-rata 1,75. Jumlah cabang simpodial berkisar antara 13,54 hingga 22,31 dengan rata-rata 17,96. Karakter umur berbunga, boll membuka dan umur panen memiliki jumlah hari minimum 54,29, 93,11 dan 120,21. Nilai maksimalnya adalah 140,22, 121,82 dan 159,77.

Untuk mengetahui tingkat galat dari suatu kelompok data digunakan Koefisien Variasi (KV). Nilai KV pada karakter-karakter yang diuji berkisar antara $8.07-12.21 \%$. Nilai KV yang tidak lebih besar dari $20 \%$ adalah baik, yang berarti galat percobaan untuk karakter-karakter tersebut relatif kecil. Secara umum dapat dikatakan, semakin besar nilai KV suatu percobaan menunjukkan bahwa derajat ketepatan percobaan tersebut semakin rendah. Nilai KV yang cukup tinggi pada karakter umur berbunga disebabkan oleh faktor genetik masing-masing aksesi, mengingat semua aksesi yang diuji berasal dari tiga spesies yang berbeda. Berdasarkan hasil analisis varians, seluruh karakter pengamatan menunjukkan perbedaan yang nyata, yaitu tinggi tanaman, jumlah cabang monopodial, dan jumlah cabang simpodial. Hal ini menunjukkan bahwa karakter-karakter tersebut memiliki respon terhadap lingkungan dan iklim tropis di lokasi pertanaman. Pernyataan ini didukung oleh Rasheed et al. (2009) yang menyatakan bahwa, beberapa karakter pertumbuhan turut dipengaruhi oleh beberapa parameter musim seperti intensitas cahaya dan suhu. Perbedaan konstitusi genetik pada aksesi-aksesi kapas yang diuji terlihat dari ciri fisik seperti bentuk daun, 
warna bunga, hairiness, dan warna tanaman (Kusuma et al., 2016), serta beberapa perbedaan morfologi lainnya.

Perbedaan yang lebih spesifik ditunjukkan pada masing-masing aksesi yang diuji seperti yang tersaji pada Tabel 3.

Tabel 3. Hasil uji BNT pada taraf 5\%

\begin{tabular}{llllllll}
\hline No & Aksesi & $\begin{array}{l}\text { Tinggi } \\
\text { Tanaman }\end{array}$ & $\begin{array}{l}\text { Cabang } \\
\text { Monopodial }\end{array}$ & $\begin{array}{l}\text { Cabang } \\
\text { Simpodial }\end{array}$ & $\begin{array}{l}\text { Umur } \\
\text { Berbunga }\end{array}$ & $\begin{array}{l}\text { Umur } \\
\text { Membuka }\end{array}$ & $\begin{array}{l}\text { Umur } \\
\text { Panen }\end{array}$ \\
\hline 1 & CRIS-664 & $140.01_{\mathrm{b}}$ & $1.23_{\mathrm{d}}$ & $19.11_{\mathrm{a}}$ & $54.41_{\mathrm{d}}$ & $94.25_{\mathrm{b}}$ & $120.32_{\mathrm{c}}$ \\
2 & CRIS-665 & $151.12_{\mathrm{ab}}$ & $1.89_{\mathrm{bc}}$ & $17.21_{\mathrm{b}}$ & $61.28_{\mathrm{d}}$ & $102.44_{\mathrm{b}}$ & $130.93_{\mathrm{bc}}$ \\
3 & CRIS-666 & $157.43_{\mathrm{ab}}$ & $1.08_{\mathrm{d}}$ & $22.31_{\mathrm{a}}$ & $59.09_{\mathrm{d}}$ & $100.12_{\mathrm{b}}$ & $128.01_{\mathrm{c}}$ \\
4 & CRIS-667 & $152.91_{\mathrm{ab}}$ & $2.13_{\mathrm{b}}$ & $21.73_{\mathrm{a}}$ & $62.44_{\mathrm{d}}$ & $105.43_{\mathrm{b}}$ & $132.54_{\mathrm{b}}$ \\
5 & CRIS-668 & $98.19_{\mathrm{de}}$ & $1.53_{\mathrm{c}}$ & $18.20_{\mathrm{ab}}$ & $61.86_{\mathrm{d}}$ & $103.92_{\mathrm{b}}$ & $130.12_{\mathrm{bc}}$ \\
6 & CRIS-669 & $123.71_{\mathrm{c}}$ & $1.01_{\mathrm{d}}$ & $18.31_{\mathrm{ab}}$ & $58.19_{\mathrm{d}}$ & $98.32_{\mathrm{b}}$ & $129.33_{\mathrm{bc}}$ \\
7 & CRIS-670 & $108.21_{\mathrm{d}}$ & $1.91_{\mathrm{b}}$ & $19.49_{\mathrm{a}}$ & $60.63_{\mathrm{d}}$ & $95.90_{\mathrm{b}}$ & $123.56_{\mathrm{c}}$ \\
8 & CRIS-342 & $79.81_{\mathrm{e}}$ & $1.73_{\mathrm{c}}$ & $17.30_{\mathrm{b}}$ & $66.28_{\mathrm{d}}$ & $93.11_{\mathrm{b}}$ & $120.21_{\mathrm{c}}$ \\
9 & Marvi-425 & $177.31_{\mathrm{a}}$ & $3.12_{\mathrm{a}}$ & $13.54_{\mathrm{c}}$ & $93.87_{\mathrm{b}}$ & $121.82_{\mathrm{a}}$ & $159.12_{\mathrm{a}}$ \\
10 & FDH-834 & $129.05_{\mathrm{c}}$ & $2.91_{\mathrm{a}}$ & $16.79_{\mathrm{b}}$ & $91.43_{\mathrm{b}}$ & $119.47_{\mathrm{a}}$ & $157.77_{\mathrm{a}}$ \\
11 & SA-2467 & $137.55_{\mathrm{c}}$ & $1.88_{\mathrm{bc}}$ & $15.34_{\mathrm{bc}}$ & $101.32_{\mathrm{b}}$ & $-*$ & $-*$ \\
12 & SA-2465 & $82.31_{\mathrm{e}}$ & $1.21_{\mathrm{d}}$ & $17.83_{\mathrm{b}}$ & $140.22_{\mathrm{a}}$ & $-*$ & $-*$ \\
13 & Kanesia 15 & $113.32_{\mathrm{d}}$ & $1.11_{\mathrm{d}}$ & $17.49_{\mathrm{b}}$ & $54.29_{\mathrm{d}}$ & $98.22_{\mathrm{b}}$ & $128.39_{\mathrm{c}}$ \\
14 & Kanesia 20 & $142.05_{\mathrm{b}}$ & $1.89_{\mathrm{bc}}$ & $16.86_{\mathrm{b}}$ & $55.85_{\mathrm{d}}$ & $99.45_{\mathrm{b}}$ & $129.43_{\mathrm{c}}$ \\
\hline
\end{tabular}

Keterangan: Angka yang diikuti dengan huruf yang sama menunjukkan tidak berbeda nyata menurut uji BNT pada taraf $5 \%$. $=$ tidak ada data

Karakter tinggi tanaman antar varietas lokal dengan kultivar introduksi memiliki perbedaan yang nyata, namun pada Kanesia 20 tidak berbeda nyata dengan CRIS 664. Gossypium arboreum memiliki karakteristik tumbuh yang lebih tinggi daripada spesies lainnya, dengan rentang 129,05 cm hingga 137,55 $\mathrm{cm}$. Perbedaan genetik yang cukup jauh menyebabkan variasi tinggi tanaman menjadi cukup beragam. Karakter cabang monopodial menunjukkan perbedaan antar aksesi, dengan jumlah paling tinggi terdapat pada aksesi Marvi-425 dan FDH-834, dengan jumlah sebanyak 3,12 dan 2,91. Cabang monopodial merupakan karakter yang dikendalikan oleh genetik dan perbedaan jumlah pada hasil penelitian disebabkan oleh berbedanya aksesi yang digunakan. Hasil ini serupa dengan laporan Jenkins et al. (1990) dan Bolonhezi et al. (1999) yang menyatakan perbedaan jumlah cabang monopodial disebabkan oleh perbedaan varietas yang digunakan.

Karakter cabang simpodial paling tinggi ditunjukkan oleh CRIS-666 dengan jumlah sebanyak 22,31. Terdapat perbedaan jumlah cabang simpodial yang cukup jauh antara kapas lokal dengan kapas introduksi. Jumlah cabang simpodial yang banyak menunjukkan indikasi potensi hasil yang tinggi, karena cabang ini merupakan cabang reproduktif yang akan menghasilkan kapas. Karakter umur berbunga paling cepat ditunjukkan oleh varietas kapas lokal, yaitu Kanesia-15, selama 54,29 hari. Adapun kultivar introduksi yang paling mendekati adalah CRIS-664, selama 54,41 hari. Hal ini menunjukkan bahwa tidak terdapat pengaruh lingkungan yang besar terhadap pembungaan pada kultivar introduksi. Perbedaan mencolok terdapat pada aksesi SA-2465 dan SA-2467 yang merupakan spesies Gossypium barbadense, dengan umur berbunga yang cukup lama, yaitu 101,32 dan 140,22 hari. Curah hujan yang cukup tinggi ketika masa generatif menyebabkan kurangnya lama penyinaran, sehingga pembungaan pun terlambat. Menurut laporan Office of the Gene Technology Regulator (2008), di habitat aslinya Gossypium barbadense memiliki umur berbunga yang sama dengan Gossypium hirsutum dan ditanam pada awal musim panas. 
Karakter umur boll membuka ditunjukkan oleh CRIS-342 dengan 93,11 hari dan tidak terdapat perbedaan yang nyata pada spesies Gossipium hirsutum. Hal ini menunjukkan bahwa kapas introduksi mampu beradaptasi pada lingkungan tropis. Adapun umur panen tercepat terdapat pada aksesi CRIS-342 dengan 120,21 hari, dan menunjukkan nilai yang tidak signifikan pada seluruh spesies Gossypium hirsutum.

\section{Evaluasi Sensitivitas Terhadap Fotoperiodisitas}

Berdasarkan hasil pengamatan, spesies Gossypium barbadense tecatat sensitif terhadap panjang hari, terlihat dari umur berbunga aksesi SA-2467 dan SA-2465. Hal ini terjadi karena tanaman introduksi tersebut lebih membutuhkan hari lebih panjang (long-day plant). Meskipun kapas ini termasuk tetraploid yang sama dengan Gossypium hirsutum, tidak menutup kemungkinan bahwa terjadinya perlambatan pembungaan (Hearn, 1981). Perlambatan terjadi karena respon genetik tanaman yang menunggu sinyal spesifik (Dingkuhn, et al., 2006). Jumlah hari hujan yang terjadi selama penelitian merupakan faktor utama inisiasi bunga pada spesies Gossypium barbadense. Diperlukan perlakuan vernalisasi pada aksesi-aksesi tersebut jika direkomendasikan sebagai sumber tetua perakitan kapas.

Adapun pada spesies Gossypium arboreum yang diuji, tidak terdapat sensitivitas. Lamanya proses pembungaan daripada Gossypium hirsutum lebih disebabkan karena faktor genetik waktu pembungaan yang lebih lambat.

\section{KESIMPULAN}

Tanaman kapas introduksi khususnya spesies Gossypium hirsutum memiliki karakter pertumbuhan dan inflorescence yang beradaptasi dengan baik pada lingkungan tropis. Aksesi CRIS-664 dan CRIS 342 bisa dijadikan sebagai tetua dengan karaktar umur genjah. Perlu dilakukan evaluasi terhadap karakter hasil sehingga mampu memberikan deskripsi yang komprehensif pada kapas-kapas introduksi tersebut.

\section{UCAPAN TERIMA KASIH}

Artikel ini merupakan bagian dari riset yang didanai oleh Indonesia Toray Science Foundation melalui penulis pertama dengan nomor STRG-01 2015. Ucapan terima kasih disampaikan kepada Dr. Mushtaque Ali Leghari (CCRIS Pakistan) dan Ir. Siwi Sumartini (Balittas Indonesia) yang telah menyediakan benih dari aksesi plasma nutfah kapas yang digunakan dalam penelitian.

\section{DAFTAR PUSTAKA}

Bolonhezi, A.C., M.M. Justi, R.C. Oliveira and C. Bolonhezi. 1999. Narrow spacing for varieties of herbaceous cotton (Gossypium hirsutum L.), plant development and retention of reproductive structures. Ribeirao Preto, SP. Brazil. 611-613. Field Crop Absrs. 53(5): 3426; 2000.

Dingkuhn, M., Singh, B.B., Clerget, B., Chantereau, J., Sultan, B. 2006. Past, present and future criteria to breed crops for water-limited environments in West Africa. Agricultural Water Management. 80 pp. $241-261$

Gibb, D., Constable, G. 1995. Cotton growth responses to water stress. Chapter 1. In: D Gibb, ed. Cotton production during drought. Cotton Research Centre for Sustainable Cotton Production, Narrabri, Australia. pp $1-13$.

Hussain, M. Ahmad, A. Zamir, S. I. 2007. Evaluation of agro-qualitative characters of five cotton cultivars (Gossypium hirsutum L.) Grown under Toba Tek Singh conditions. Pak. J. Agri. Sci., Vol. 44(4). 
Kusuma, J dan Tahir, M: Evaluasi Karakter Pertumbuhan dan Inflorescence Plasma Nutfah ...

Jenkins, J. N., McCarty, J. C., and Parrott, W.L. 1990. Effect of genotype on fruiting efficiency in cotton, the boll size and boll percentage. Crop Sci. 30:857-860.

Kusuma, J., Gusta, A. R., Abdullah, K., Ahsan, M. Z., dan Tahir, M. 2016. Karakteristik Keragaman Morfologi dan Deskripsi Sifat Vegetatif pada Beberapa Plasma Nutfah Kapas Hasil Introduksi. Prosiding Seminar Nasional Pengembangan Teknologi Pertanian. ISBN 978-602-70530-4-5 halaman $106-112$.

Office of the Gene Technology Regulator. 2008. Biology of Gossypium hirsutum and Gossypium barbadense. Australian Government.

Petersen, R.G. 1994. Agricultural Field Experiment Design and Analysis. Morcel Dekker Inc. New York. P 36-48.

Rasheed, A., W. Malik, A.A. Khan, N. Murtaza, A. Qayyum and E. Noor, 2009. Genetic evaluation of fibre yield and yield components in fifteen cotton (Gossypium hirsutum) genotypes. Int. J. Agric. Biol., 11: $581-585$.

Reddy, K. R., Reddy, V. R., Hodges, H. F. 1992. Temperature effects on early season cotton growth and development. Agronomy Journal. 84: 229 - 237.

Saeed, F., T. Salam and M.I. Khan. 1996. Gene action in intraspecific hybrids of cotton (Gossypium hirsutum L) for yield parameters. Sarhad J. Agri., 12: 653-661.

Wankhade, S.T. and A.K. Gobble. 2002. Performance of different cotton (Gossypium hirsutum L.) cultivars at different nitrogen rates. Annals of Plant Physiology, 1(4): 569-571. 